\title{
ANALYSIS EFFECT OF MUDHARABAH FINANCING SHARING ON PROFITABILITY AT BRI SYARI'AH KCP CIAMIS 2014-2020
}

\author{
Helmi Maulana \\ Institut Agama Islam Darussalam (IAID) Ciamis-Jawa Barat \\ Email: helmi.maulana@iaid.ac.id \\ Dedeh Nurwahidah \\ Institut Agama Islam Darussalam (IAID) Ciamis-Jawa Barat \\ Willa Maulida \\ Institut Agama Islam Darussalam (IAID) Ciamis-Jawa Barat
}

\begin{abstract}
As an institution engaged in the financial sector, Islamic banks expect benefits from the activities that have been carried out. This profit is generated through income generated from the products that are distributed. The performance of banks in carrying out their activities is seen from how much financing is distributed because the source of income for Islamic banks is from financing distribution. The volume of financing provided by Islamic banking needs to show an increase in order to create healthy and efficient financial institutions. Healthy financial institutions are able to demonstrate the ability to increase profits through increased profitability. The higher the profitability of a bank, the better profits or profits will be generated by the bank. Return on Assets (ROA) is one of the financial ratios in banking which has the best role to reflect the level of profitability of the bank. This research method uses quantitative descriptive method where quantitative descriptive method is a method in examining the status of a human group, an object, a set of conditions, a system of thought, or even a group of events in the present which aims to make a description. This research uses simple regression analysis which includes partial test ( $t$ test), and coefficient of determination test (R2). From the partial test ( $t$ test) obtained $t$ count of $10.027>$ from the value of $t$ table of 2.228139. It is known that the p-value $<(0.000<0.05)$ indicates that the multi-finance variable has a significant effect on Return On Assets (ROA). Coefficient of Determination Test (R2) regression model, the adjusted R2 value is 0.900 , which means that the dependent variable can be explained by the independent variable by $90 \%$, while the remaining $10 \%$ is explained by other variables not included in the regression model. The results of the partial test (t-test) and the coefficient of determination (R2) show that murabahah financing has a significant effect on the Return on Assets (ROA) profitability ratio at BRI Syariah KCP Ciamis Bank for the 2018-2020 period.
\end{abstract}

\begin{abstract}
Abstrak
Sebagai lembaga yang bergerak di bidang keuangan, bank syari'ah mengharapkan adanya manfaat dari kegiatan yang telah dilakukan. Laba ini dihasilkan melalui pendapatan yang dihasilkan dari produk-produk yang disalurkan, kinerja perbankan dalam menjalankan aktivitasnya dilihat dari seberapa besar pembiayaan yang distribusikan karena sumber pendapatan bank syari'ah dari penyaluran pembiayaan. Volume pembiayaan yang diberikan oleh perbankan syariah perlu menunjukkan peningkatan dalam rangka menciptakan lembaga keuangan yang sehat dan efisien, lembaga keuangan yang sehat mampu menunjukkan kemampuan untuk meningkatkan
\end{abstract}


keuntungan melalui peningkatan profitabilitas semakin tinggi profitabilitas suatu bank maka semakin baik keuntungan atau keuntungan akan dihasilkan oleh bank. Return on Assets (ROA) merupakan salah satu rasio keuangan dalam perbankan yang memiliki peran terbaik untuk mencerminkan tingkat profitabilitas pada bank. Metode penelitian ini menggunakan metode deskriptif kuantitatif dimana metode deskriptif kuantitatif adalah suatu metode dalam meneliti status kelompok manusia, suatu objek, seperangkat kondisi, sistem pemikiran, atau bahkan suatu golongan peristiwa pada masa sekarang yang bertujuan untuk membuat deskripsi. , gambar atau lukisan secara sistematis, faktual dan akurat tentang fakta, sifat dan hubungan antara fenomena yang diselidiki. Penelitian ini menggunakan analisis regresi sederhana yang meliputi uji parsial (uji t), dan uji koefisien determinasi (R2). Dari Uji Parsial (uji t) diperoleh t hitung sebesar 10,027 > dari nilai t tabel sebesar 2,228139. Diketahui bahwa p-value < $(0,000<0,05)$ menunjukkan bahwa variabel pembiayaan multifinance berpengaruh signifikan terhadap Return On Assets (ROA). Uji Koefisien Determinasi (R2) model regresi besarnya nilai adjusted R2 sebesar 0,900 yang berarti variabel terikat dapat dijelaskan oleh variabel bebas sebesar 90\%, sedangkan sisanya 10\% dijelaskan oleh variabel lain yang tidak termasuk dalam model regresi. Hasil uji parsial (uji t) dan uji koefisien determinasi (R2) menunjukkan bahwa pembiayaan murabahah berpengaruh signifikan terhadap rasio profitabilitas Return on Asset (ROA) pada Bank BRI syari'ah KCP Ciamis periode 2018-2020.

Keywords: Profitability, Return on Asset (ROA), Murabahah

\section{Introduction}

Bank is a business entity whose main task is as a financial intermediary institution that channel funds from party who over-funding to parties who need funds or lack of funds. In practice the bank is divided into two conventional banks and syari'ah banks. The development of syari'ah banking in Indonesia, influenced by various things. One of them is the principle used by syari'ah bank in its operational activities, where in conducting its business activities, syari'ah bank implements a system of profit sharing (loss and profit sharing) in sharing profit or loss between customer and bank and margin in sale transaction buy it.

As an institution engaged in finance, syari'ah banks expect the benefits of activities that have been done. This profit is generated through the revenue generated from the products distributed, the products in the shariah banking is divided into three groups: fund raisers, fund distribution products, and other banking services. Of the three groups of products the bank earns revenue through the profit sharing ratio and margin of sale that have been agreed upon at the beginning of the contract.

The performance of banking in carrying out its activities is seen from how much financing is channeled because the source of income of syari'ah bank is from the distribution of financing. The volume of financing provided by sharia banks needs to show an increase in order to create a healthy and efficient financial institution, because a healthy financial institution is able to demonstrate the ability to increase its profitability through increased profitability, so that more and more people who use sharia banking services in transacting in everyday life.

The level of profitability is an appropriate indicator to measure the company's performance in running its business activities. Because the higher the profitability of a bank the better the profit or profit that will be generated by the bank. Return on Assets 
(ROA) is one of the financial ratios in banking that has the best role to reflect the level of profitability in the bank. Return on Assets (ROA) is used to measure the ability of bank management to earn profits as a whole, because the greater the Return on Assets (ROA) in the bank, the greater the level of profit or streak gan achieved by the bank and the better the bank's position in terms of asset use.

In this research, the writer tries to investigate whether the financing of murabahah in BRI bank syari'ah KCP Ciamis has a level of profitability measured using the ratio of financial ratios Return on Assets (ROA) has an influence on the bank's income and seen from the important role of murābahah that largely dominate in its marketing in bank BRI syari'ah KCP Ciamis period 2018-2020.

\section{Theoretical Review}

According to Law no. 10 Year 1998 on banking, defines the bank as a business entity that collects funds from the public in the form of savings and channeled to the community, in the form of credit and or other forms in order to improve the standard of living of many people. Based on Article 5 of Law no. 10 Year 1998, concerning banking, there are two types of banks, namely Commercial Banks and Rural Banks. Both types of banks are in running their business activities are classified into two, namely conventional banks and banks with the principles of shari'ah.

According to Hasan (2008: 1) syari'ah bank consists of two words, namely banks and shari'ah. The word bank means a financial institution that serves as a financial intermediary of two parties, the party is excessive funds and the lack of funds. The word syari'ah in the version of syari'ah bank in Indonesia is a rule of agreement based on that done by the bank and other parties for the storage of funds and financing of business activities and other activities in accordance with Islamic law.

However, in shariah banks and conventional banks have a very real difference where in the shari'ah bank contract the principle that concerns the consequences of the world and ukhrawi because the contract that occurs is the principle of Islamic law.

According to Umam (2018: 19) the implementation of the banking function has actually become a tradition since the time of Rasullulah, such as financing, custody of treasures, borrow money, even remittances. However, at that time, the banking functions are still very simple and individual in accordance with the needs of the community, so not systematically institutionalized. In fact, Islam also has a fairly comprehensive rule about the laws of an economy, which can be explored further in the Qur'an, hadith or books by scholars. For example the term keredit (Qard), Check (Suquq), and so forth.

The theoretical concept of an Islamic bank first appeared in the 1940s, with the idea of a profit-sharing banking. With regard to this can be mentioned the thoughts of the authors, among others Anwar Qureshi (1946), Naiem Siddiqi (1948) and Mahmud Ahmad (1952). A more detailed description of the preliminary notion of Islamic banking was written by the great scholars of Pakistan, namely Abul A'la Al-Mawdudi (1961) and Muhammad Hamidullah (1944-1962).

The first modern attempt to establish a flowerless bank began in Pakistan that administered the pilgrim fund in the mid-1940s, but this effort was unsuccessful. The next development of the most successful and innovative establishment of modern sharia bank in modern times was done in Egypt in 1963, with the establishment of Mit 
Ghamr Local Saving Bank. The bank is well-received by farmers and rural communities. Unfortunately, due to political turmoil in Egypt, Mit Ghamr began to decline, so that its operations were taken over by the National Bank of Egypt and the Egyptian central bank in 1967. This takeover caused the interest principle on Mit Ghamr to be abandoned, so the bank resumed operations based on flower. In 1971, finally the concept of non-interest back dibankitkan during the Sadat regime through the establishment of Naseer Social Bank. The purpose of this Bank is to re-run the business based on the concept that has been practiced by Mit Ghamr.

The first private Islamic bank in Dubai is Dubai Islamic Bank, founded in 1975 by a group of Muslim entrepreneurs from various countries. In 1977 stood two Islamic banks under the name Faysal Islamic Bank in Egypt and Sudan. And in that year the Kuwaiti government established Kuwait Finance House.

According to Antonio (2001: 25) the development of sharia banks in Islamic countries influential to Indonesia. In the early 1980 , discussions about sharia banks as pillars of Islamic economics began. The figures involved in the study were Karnaen A. Perwataatmadja, M. Darmawan Rahardjo, A.M, Saefuddin, M. Amien Azis, and others. The more specific initiative to establish an Islamic bank in Indonesia was conducted in 1990. The Indonesian Ulema Council (MUI) on 18-20 August 1990 hosted a bank interest workshop and deliberated in the IV National MUI meeting on 22-25 August 1990. Be based on the mandate of Munas IV MUI formed a working group to establish an Islamic bank in Indonesia.

The result of this MUI group work, is the formation of the first bank based syari'at Islam namely PT. Bank Muamalat Indonesia (BMI).

According to Hasan (2008: 138) in his activities as a financial institution, sharia banks and conventional banks have the same function that is the technical side of money receipts, transfer mechanisms, computer technology used, general terms of obtaining financing such as KTP, NPWP, Proposal, financial statements, and so forth. The differences only concern the legal aspect, organizational structure, business financed, and the working environment. In the shari'a bank the contract is carried out to have worldly and ukhrawi consequences because the contract is done under Islamic law. Siamat (2004: 192) in channeling funds to customers, broadly there are three groups of financing in syari'ah banks, namely the principle of profit sharing (syirkah), the principle of sale and purchase (bai '), and lease purchase.

In general, the principle of profit sharing in syari'ah banking can be done in four main contracts namely al-musharaka, al-mudhârabah, al-muzara'ah, and almusaqah. Al-musharaka, is a contractual agreement between two or more parties for a particular business, in which each party contributes funds, with a profit or risk to be borne together in accordance with the original contract. al-mudhârabah, is a cooperation contract between two parties where the first party provides all capital, while the second party becomes the manager. Profits in al-mudhârabah are divided on the basis of the original contract. Whereas if the loss, the loss is borne by the owner of the capital during the loss is not from the negligence of the manager. al-muzara'ah, is an agricultural processing cooperation between landowners and tenants, in which the landowner gives farmland to be managed by the cultivator to be planted or harvested in exchange for (Percentage) of the agricultural produce in accordance with an agreed agreement. al-musaqah, is the simplest form of al-muzara'ah where the cultivator is 
only responsible for the maintenance and watering, in return the tiller is entitled to receive the ratio of the crops earned in accordance with the initial agreement.

From syari'ah bank products there is a buying and selling system of murabahah which is a buying and selling contract in which the bank acts as a temporary seller of the customer as a buyer. The selling price is the purchase price of the bank plus the profit. In this transaction the goods are delivered immediately after the contract, while the payment can be done in cicil (Bitsaman Ajil) or simultaneously.

In technical banking, murâbahah is a contract of sale and purchase between the bank as the provider of goods (seller) with customers who order to buy goods. The Bank benefits from a mutually agreed sale. Rukun and murabahah requirements are the same as the terms and conditions in fiqh, while other conditions such as goods, prices and payment methods are in accordance with the policy of the bank concerned. The selling price of the bank is the purchase price of the supplier plus the mutually agreed profits. So the customer knows the profit taken by the bank.

According to Haryono, (2009: 84) murâbahah is an agreement for sale and purchase transactions between banks as sellers and customers as buyers of goods at the acquisition price plus agreed (margin) profit and with complete and transparent information (honest) between two parties. Meanwhile, according to Antonio, (2001: 101) murâbahah is the sale and purchase of goods at the price of origin with additional benefits agreed. In murābahah, the seller must tell the price of the product he purchased and determine a profit level as an additional. Thus, it is clear that in sharia banking there is no activity that violates the rules of shari'ah is usury.

1. The Foundation, Rukun and Terms Murābahah

29. O you who believe! Fulfill your neighbor's treasures in the same way, save by the way of commerce that applies equally to you. and kill not yourselves; Allah is Most Merciful to you. (Q.S An-Nissa, 2: 29). 39. and something of Riba (addition) that you give in order for Him to increase in the treasure of man, then Riba does not add to the side of God. and what you give in the form of zakat that you intend to achieve the pleasure of Allah, Then (the ber make it so) That is the people who multiply (reward). (Q.S Ar-Ruum, 30: 39). Hadith About Financing murâbahah: Hadith of the Prophet of Said al-Khudri: From Abu Sa'ad Al-Khudri that the Messenger of Allah (saws) said: "Truly the buying and selling must be done likes the same." (HR Al-Baihaqi and Ibn Majah, and judged saheih by Ibn Hibban). Wijaya (2001: 119) bank profitability is a tool to analyze tools to measure the level of business efficiency achieved by a company concerned, in addition profitability is defined as the ability of banks in generating Profit.

Profitability ratio is used to measure the success and effectiveness of management in generating a profit or profit in a certain period. Profitability in the bank can be known by analyzing the financial statements, and from the results of the analysis will be reflected the ability of banks in obtaining profit or profit. The ratio to measure the level of profitability is Return On Assets (ROA) is the ratio between net income (net income) with average assets (average assets). Profits for bank owners are the result of profitability and leverage levels that can be used. 


\section{Methods}

The type of research method used is quantitative research method. This method is called a positivistic method because it is based on the philosophy of positivism. This method as a scientific or scientifie method because it has met the scientific principles that are concrete or empirical, objective, measurable, rational, and systematic. This method is also often called the confirmatory method, because this method is suitable to be used for verification / confirmation. This method is called quantitative method because the research data in the form of numbers and analysis using statistics. (Sugiyono, 2019: 11)

Sources of data obtained through a direct review of the object of research to obtain the necessary data. This research was conducted on the activities of all research objects, including observation, Interview, Documentation. Direct observation on the object of research in order to obtain concrete evidence and information that will support the results of research at the bank BRI Syari'ah KCP Ciamis. Interview by Supriyati (2014:48) is a common and powerful way to understand a desire or need, or technique of data retrieval through questions posed orally to the respondent.

Techniques of data collection conducted by holding the recording and collection of data in the identification of documents that have relation to the research to be conducted. Document analysis leads more to concrete evidence. in analyzing this document the author can get data that support the research. Sujarweni (2020: 95). This research was conducted by collecting data from various relevant literature and studying matters related to the problem to be discussed. The data obtained from literature study is a source of information that has been found by experts who are competent in their field, in this literature study the author tries to collect data from several references.

\section{Results and Discussion}

The type of data used in this study is Primary data. Primary data is data obtained and is raw or unprocessed. Primary data has not been able to provide information in decision making so it needs to be processed further. (Wijaya, 2018: 19). The data collection instrument is a tool or facility used by the researcher in collecting data to make the work easier and the result is better, in a more thorough, complete and systematic meaning easier to process (Sujarweni 2019: 76).

The data obtained are primary data derived from the financial statements of murabahah financing and profitability ratio in bank BRI syari'ah KCP Ciamis period 2018-2020 per-Quarter. According Sujarweni (2020: 121) understanding of data analysis is defined as the effort data that is available and then processed with statistics and can be used to answer the problem formulation in research. Thus the technique of writing data analysis can be interpreted as a way to analyze data, with the aim of processing the data to answer the problem formulation.

Meanwhile, according to Sugiyono (2010: 207) states that "activities in data analysis is to group data based on variables of all respondents, presents data of each variable studied, perform calculations to answer the formulation of the problem, and perform calculations to test the hypothesis that has been done. "Technique done in this research is quantitative data.

In analyzing the data that the author obtained from the observation (research) it will be used appropriate technique that is with descriptive data, thus the collected data 
then collected and can be analyzed, so there will be problems that arise and can be clearly described.

In this writing, the author uses the technique of data analysis as follows:

1. Descriptive Analysis Method

According to Nazir (1988: 63) descriptive method is a method in examining the status of a group of people, an object, a set of conditions, a system of thought or a class of events in the present. The purpose of this descriptive study is to create a description, description, or painting systematically, factually and accurately about the facts, properties and relationships between phenomena investigated. According Sugiyono (2005: 21) states that the descriptive method is a method used to describe or analyze a research results but not used to make wider conclusions.

2. Quantitative Analysis Method

Quantitative data analysis is a form of analysis using numbers and calculations with statistical methods to test the truth of the research hypothesis that has been proposed previously. Thus the data that has been collected, then concluded and can be interpreted, so the problem can be interpreted and described clearly in the research. Data in this research will be analyzed by method:

3. Classic Assumption Test

a. Test Data Normality

Ghozali (2014: 160) normality test aims to test whether in the regression model, disruptive or residual variables have a normal distribution, if this assumption is violated then the statistical test becomes invalid for the small number of samples. According to Santoso (2001: 214) there are several ways of detecting normality by looking at the spread of data (dots) on the diagonal axis and graph. Basic decision making:

1) If the data spreads around the diagonal line and follows the direction of the diagonal line, then the regression model meets the assumption of normality.

2) If the data spreads far from the diagonal line and or does not follow the direction of the diagonal line, then the regression model does not meet the assumption of normality.

3. Simple Regression Analysis

According Sugiyono (2014: 261), stated that simple regression is based on the functional or causal relationship of one independent variable with one dependent variable. Sugiyono (2010: 230) argued that "hypothesis testing using t test is a hypothesis testing to see whether or not the influence caused by independent or independent variables are separate or individually to dependent or dependent variables. Furthermore Sugiyono (2019: 64) Independent Variables are often called stimulus variables, predators, antecedent, in the Indonesian language is often called the independent variable. The independent variable is a variable that influences or becomes the cause of the change or the incidence of the variables dipenden (Bonded). While Independent variables are often referred to as output variables, criteria, consequent. In the Indonesian language is often called the dependent variable. The dependent variable is the variable that is affected or the result, because of the independent variables.

The provisions in this test are as follows:

1) If the level of significance is $<5 \%$, Ho is rejected and Ha accepted. 
2) If the level of significance $>5 \%$, Ho accepted and Ha rejected.

The conclusion is:

3) Accept Ho if p-value <level of significant.

4) Accept Ha if $\mathrm{p}$-value > level of significant

Ho: Muraiah financing does not affect the profitability of BRI Syari'ah KCP Ciamis period 2018-2020.

Ha: Murabahah financing affects the profitability of BRI Syari'ah KCP Ciamis period 2018-2020.

b) Coofisien determination test (R2)

According Ghozali (2014: 97) coefficient of determination (R2) in essence measure how far the ability of the model in explaining the variation of the dependent variable. The coefficient of determination is between zero and one. The small value of R2 means the ability of the independent variables to explain the variation of the dependent variable is very limited. A value close to one means the independent variables provide almost all the information needed for $\mathrm{m}$ emprediction of variation of dependent variable.

The coefficient of determination is between zero and one, if the value is small or close to zero then the variation of the dependent variable is very limited. Whereas if the value is large or close to one then almost all the information needed to predict the dependent variable. According to Bhuono (2005: 51) R-Square value is said to be good if it is above 0.5 because $\mathrm{R}$-square value ranges from $\mathrm{O}$ to 1 . In general, sample with time series data has R-Square and Adjusted R-Square quite high (above 0.5). In general, R-square or Adjusted R-Square is quite low (below 0.5).

Research variable is an attribute or the nature or value of people, objects or activities that have certain variations set by researchers to be studied and then drawn conclusions (Sugiyono, 2007: 38). From this research is expected to produce a descriptive picture about factor of independent variable which have significant or not significant to profitability level at multifahah financing. Operational variables of this research consist of:

a. Dependent Variable

Dependent Variable (Dependent Variable) is an influenced variable (response) or a variable whose value depends on the change of other variables. In this study the dependent variable is the level of profitability.

b. Variable Free (Independent Variable)

Independent Variables are often referred to as stimulus, predictor, antecedent variables. Is a variable that affects or be the cause of the change or the emergence of the dependent variable (bound). In this study, the dependent variable is murabahah financing.

Based on the results of research in the analysis using a simple regression test that includes Partial Test (Test $t$ ) and Determination Koofesien Test (R2). Then it can be deduced: Partial Test ( $\mathrm{t}$ test) is known that the obtained value of $\mathrm{t}$ count equal to $10,027>$ from ttable equal to 2,228139 and $p$-value value $<\alpha(0,000<0,05)$. Thus it can be concluded that murabahah financing variables have a significant influence on Return On Assets (ROA). Determination Coofesien Test (R2) explains that the correlation of multifarious financing variables on Return On Assets (ROA) has a big influence due to the value of adjusted R2 of 0.900 which means the dependent variable can be explained by independent variable of $90 \%$, while the remaining $10 \%$ is explained 
by other variables not included in the regression model. So Ho is rejected and Ha accepted. From the overall analysis result that has been described above is known that murâbahah financing has a significant effect on Return On Assets (ROA) period 20182020. The reason is because:

1) People in eastern partisan majority of muslim so awareness to switch to syari'ah bank big enough.

2) Murabahah financing in Bank BRI Syari'ah KCP Ciamis more marketed than financing Sale and Purchase or profit sharing, because financing murâbahah have a small risk to be marketed to the public.

Relevant research according to Awib (2017: 86) indicates that financing murâbahah affect on Return On Assets (ROA) this is stated based on the results of $t$ test financing murâbahah with tcount $=5,502$ and probability of $0.000<0.005$. This means that in this study $\mathrm{H} 1$ accepted so financing murâbahah effect on Return On Assets (ROA).

\section{Conclusion}

Based on the results of the analysis conducted by using a simple regression analysis model regarding the influence of independent variables ie murabâhah financing to the dependent variable that is Return On Assets (ROA) at bank BRI syari'ah KCP Ciamis starting from January 2018 until December 2020. So from the results this research can be concluded: (1) Average of murabahah financing in 2018 Bank BRI Shari'ah KCP Ciamis of 55 financing, then in 2019 the average amount of financing murâbahah as much as 98 financing, in 2020 the average amount of financing mningkat that is as much as 335 financing. So it can be concluded that every year financing murâbahah increase. (2) Average Return On Assets (ROA) generated by Bank BRI Syari'ah KCP Ciamis in the year 2018 amounted to $39.10 \%$ and in the year 2019 average Return On Assets (ROA) increased by $78.8 \%$ to $117,10 \%$ while in 2020 Return On Assets (ROA) again increased by 119.92\% from the previous year which is 237.82\%. This means that the profitability of BRI Syari'ah KCP Ciamis bank includes banks that have a healthy Return On Assets (ROA). (3) That partially obtained tcount of $10,027>$ from ttable equal to 2,228139 and $p$-value value $<\alpha(0,000<0,05)$. Thus it can be concluded that the murabah financing variable has a significant influence on Return On Assets (ROA). Whereas the result of the research shows that the financing variable of murâbahah has a co-value of 0,900 which means dependent variable which can be explained by independent variable equal to $90 \%$ while the remaining $10 \%$ is generated from other variable not included in the regression model.

\section{REFERENCES}

Antonio, M. Syafi.i. (2001). Bank Syari.ah from Theory to Practice. Jakarta: Gema Insani Press.

Bhuono Agung, Nugroho. (2005). Strategy to Select Method of Statistical Research with SPSS. Yogyakarta: ANDI. 
Dahlan, Siamat. (2004). Management of Financial Institutions. Fourth Edition. Jakarta: Lembaga Penerbit Fakultas Ekonomi Universitas Indonesia.

Dendawijaya, Lukman. (2005). Banking management. Issue 2. Ghalia Indonesia: Bogor.

Ghozali, Imam. (2014). "Application of Multivariate Analysis With SPSS Program”. Semarang: Diponegoro University Publishing Agency.

Haryono, Yusuf. (2009). Fundamentals of Accounting. Yogyakarta: STIE YKPN.

Hasan, Ali. (2008). Marketing. Yogyakarta: Media Utama.Mervyn, K. Lewis (2001). Syariah banking. Jakarta: Serambi

Muhammad. (2005). Shariah bank management. Yogyakarta: YKPN AMP publishing and printing unit.

Nazir, Mohamad. (1988). Research methods. Jakarta: Ghalia Indonesia.

Santoso, Singgih. (2001). Processing Professional Statistics Data. Jakarta: PT. Alex Media Komputindo.

Siamat, Dahlan. (2004). Management of Financial Institutions. Fourth Edition. Jakarta: Lembaga Penerbit Fakultas Universitas Indonesia.

Sugiyono. (2005). Understanding Qualitative Research. Bandung: ALFABET.

--------. (2007). Business Research Methodology. Jakarta: PT. Gramedia.

---------. (2008). Research Methods Administration. Bandung: Alfabeta.

--------. (2010) Qualitative Quantitative Research Methods and R \& D. Bandung: Alfabeta.

. (2014). Educational Research Methods (Quantitative Approach, Qualitative, and R \& D). Bandung: Alfabeta.

---------. (2015). Educational Research Methods. Bandung: Alfabeta.

----------. (2019). Qualitative Quantitative Research Methods and R \& D. Bandung: Alfabeta.

Sujarweni, V. Wiratna. (2019). SPSS For Research. Yogyakarta: New Library Press.

V. Wiratna. (2020). Public Sector Accounting Theory, Concepts, Applications. Yogyakarta: New Library Press.

---------. V. Wiratna. (2020). Business \& Economic Research Methodology. Yogyakarta: Pustakabaru press.

Supriyati. (2014). Learn Basic Accounting. Bandung: LABKAT PRESS UNIKOM.

Umam, Khaerul. (2018). Management of Syari'ah Banking. Bandung: CV. Faithful Library.

Wijaya, Tony. (2018). Terori Economic and Business Research Methods and Practice. Yogyakarta: Graha Ilmu. 